\title{
Sciendo
}

DOI: $10.1515 /$ sspjce-2019-0024

\section{Research of building structures in extreme climate conditions}

\author{
Dušan Katunský, Lenka Kabošová, Erika Dolníková, Marek Zozulák \\ Technical University of Košice, Slovakia \\ Faculty of Civil Engineering, Institute of Architectural Engineering \\ e-mail: dusan.katunsky@tuke.sk
}

\begin{abstract}
The paper provides information on the solution of project supported by the Scientific Grant Agency of VEGA of the Ministry of Education, Science, Research and Sports of Slovak Republic and of the Slovak Academy of Sciences of Slovak Republic. There is project: VEGA 1/0674/18. This research project is programmed for the years 2018 to 2021. In this paper are presented information on the results obtained in 2019, solution of this project objectives and project solution. The results are presented in realized publications. We focused mainly on the presentation of major publications, articles in domestic and foreign journals, articles in conference proceedings with an emphasis on publications that are indexed in the WOS and SCOPUS databases.
\end{abstract}

Key words: building structures, architecture, envelope structures, thermo-moisture properties, light-technical properties, constructional-architectural shapes,

\section{Introduction}

The content of the project is theoretical analysis and experimental research of architecturalstructural shapes of buildings, fragments and details of building envelope, their physical properties, i.e. (aerodynamic, thermal, humidity, energy) as well as material parameters, their packaging structures designed for extreme external climate conditions (wind, snow, rain, temperature differences). The research is carried out under real conditions (in situ) and laboratory research in the construction of experimental models. The project builds on the results obtained so far. In real terms, the effects of wind, temperature, external climate humidity, as well as energy flows through cladding are characterized by non-stationary processes. The task of the project is therefore to analyze these impacts, in particular the aerodynamic, thermal, humidity and energy impacts on the building as a whole, as well as these effects on the packaging structures, exposed to extreme external climate conditions (both experimental and real in situ measurements). 


\section{Content of the project and research}

The project aims to meet three basic objectives:

I. The first objective is laboratory measurements and calculations of selected aerodynamic parameters of building envelope structures, architectural and structural shapes of buildings that determine the behavior of building structures and the building as a whole under extreme wind conditions.

II. The second objective is to monitor selected parameters (physical quantities) of fragments and details of cladding (temperature and humidity changes).

a) exposed to laboratory conditions (indoor stand),

b) exposed to real conditions (experimental chambers).

c) exposed to real conditions in situ (on site, in a building).

III. The third objective is laboratory measurements of physical parameters of building materials that are exposed to extreme conditions in building envelope structures. Inputs: Experience gained on the basis of long - term measurements of material and physical characteristics of fragments and construction details in real conditions of exploitation of the construction work - in situ, further knowledge from research in the given area (projects solved so far).

IV. General conclusions outputs:

a) Models of architectural and structural shapes of buildings,

b) Packaging structures, e. j. building fragments in extreme external climate conditions as a reliable tool for optimizing the structural detail of a building.

c) Parameters (physical quantities) - verification model for numerical simulations.

Table 1: Description of the content of the members of the team to solve the project in. 2019/2020

\begin{tabular}{|c|c|c|c|}
\hline \multirow{2}{*}{$\check{c}$} & \multicolumn{3}{|c|}{ Team } \\
\hline & name & position & function \\
\hline 1 & Katunský Dušan, prof. Ing. CSc. & professor & project leader \\
\hline 2 & Vertal' Marián, doc. Ing. PhD & assoc-prof & deputy head, hygro-thermal properties \\
\hline 3 & Lopušniak Martin, doc. Ing. PhD & assoc-prof & coordination between projects \\
\hline 4 & Bullová Iveta, Ing. PhD & assist prof. & aerodynamic properties \\
\hline 5 & Dolníková Erika, Ing. PhD & assist prof. & light-technical properties \\
\hline 6 & Katunská Jana, Ing. PhD & assist prof. & thermal and energy properties \\
\hline 7 & Tóth Stanislav, Ing. PhD & assist prof. & packaging constructions \\
\hline 8 & Zozulák Marek, Ing. PhD & assist prof. & thermo-moisture properties, laboratory research \\
\hline 9 & Szénay Martin, Ing. PhD. & PhD-studet & fire lifts (completed PhD in August 2019) \\
\hline 10 & Kabošová Lenka, Ing. arch. & PhD-studet & structural and architectural shapes of buildings \\
\hline 11 & Špaková Miroslava, Ing. (MD) & PhD-studet & research of wood structures \\
\hline 12 & Karl'a Viktor, Ing. arch. & PhD-studet & transparent wood, static properties \\
\hline 13 & Jaroš Pavol, Ing. & PhD-studet & hygro-thermic properties of sandstone \\
\hline 14 & Tomková Želmíra, Ing. arch. & PhD-studet & LCA (life cycle assessment) \\
\hline 15 & Baroš Tomáš, Ing. & PhD-studet & parazitic architekture \\
\hline
\end{tabular}

The project is solved by a team consisting of colleagues from the Institute, members are one professor, two associate professors, five lecturers and seven doctoral students, which together 
make 15 researchers. Each member of the team has its own role and content, which is devoted to.

Methods: Theoretical analysis, synthesis, confrontation, simulation, experiment. In experimental facilities realization of measurements on test models using monitoring elements in cooperation with a device for monitoring changes of conditions of demanding external climate:

a) Calculations, simulations, mathematical modeling, obtaining boundary conditions,

b) Production of models of architectural and structural shapes of buildings, fragments,

c) Measurements, data analysis, confrontation of measurements and calculations.

\section{Project results}

The project was solved in the previous year by the team, which is shown in Table 1 . Individual researchers published their results in journals, proceedings and presented at conferences. Individual publications touched on the main points, which are the basic objectives and subjects of observation:

1) Designs of structural and architectural shapes

2) Aerodynamic properties

3) Lighting properties

4) Energy assessment of buildings

5) Heat-moisture properties

6) Properties of materials, sandstone, transparent wood

7) LCA method

Individual points are filled with publications in which it is stated what has been achieved. The following points can be mentioned for individual points:

\subsection{Design of structural and architectural shapes}

Ing. arch. Lenka Kabošová was most active doctoral student at this point [1], [2]. She deals with extreme wind influence on the creation of architectural and structural shapes of buildings in dissertation thesis. She has prepared a number of publications that have been published or are ready for publication in journals and proceedings under the guidance of a specialist consultant Professor Kmet'. In 2019 these were the following publications:

1) Digitally Designed Airport Terminal Using Wind Performance Analysis / Kabosova, Kmet, Katunsky - 2019, In: Buildings (CH)

2) Hybrid Design Method for Wind-Adaptive Architecture / Kabosova [et al.] - 2019, In: International Journal of Architectural Computing - SAGE Publications London (GB)

3) Building Envelope Adapting from / to the Wind Flow / Kabosova [et al.] - 2019, In: Architecture in the Age of 4th Industrial Revolution Volume 2 Education and Research in Computer Aided Architectural Design in Europe - Porto (PT)

4) The interactions of wind and architectural shape / Kabosova - 2019, In: Seminar of PhD students 2019: in field: PS - TUKE Košice (SK) 
5) The search for an optimal architectural shape using wind performance analysis / Kabosova - 2019, In: YS2019 - Young Scientist 2019: Proceedings of the 11th International Scientific Conference on Civil and Environmental Engineering for $\mathrm{PhD}$. Students and Young Scientists - IOP Publishing, Bristol (GB)

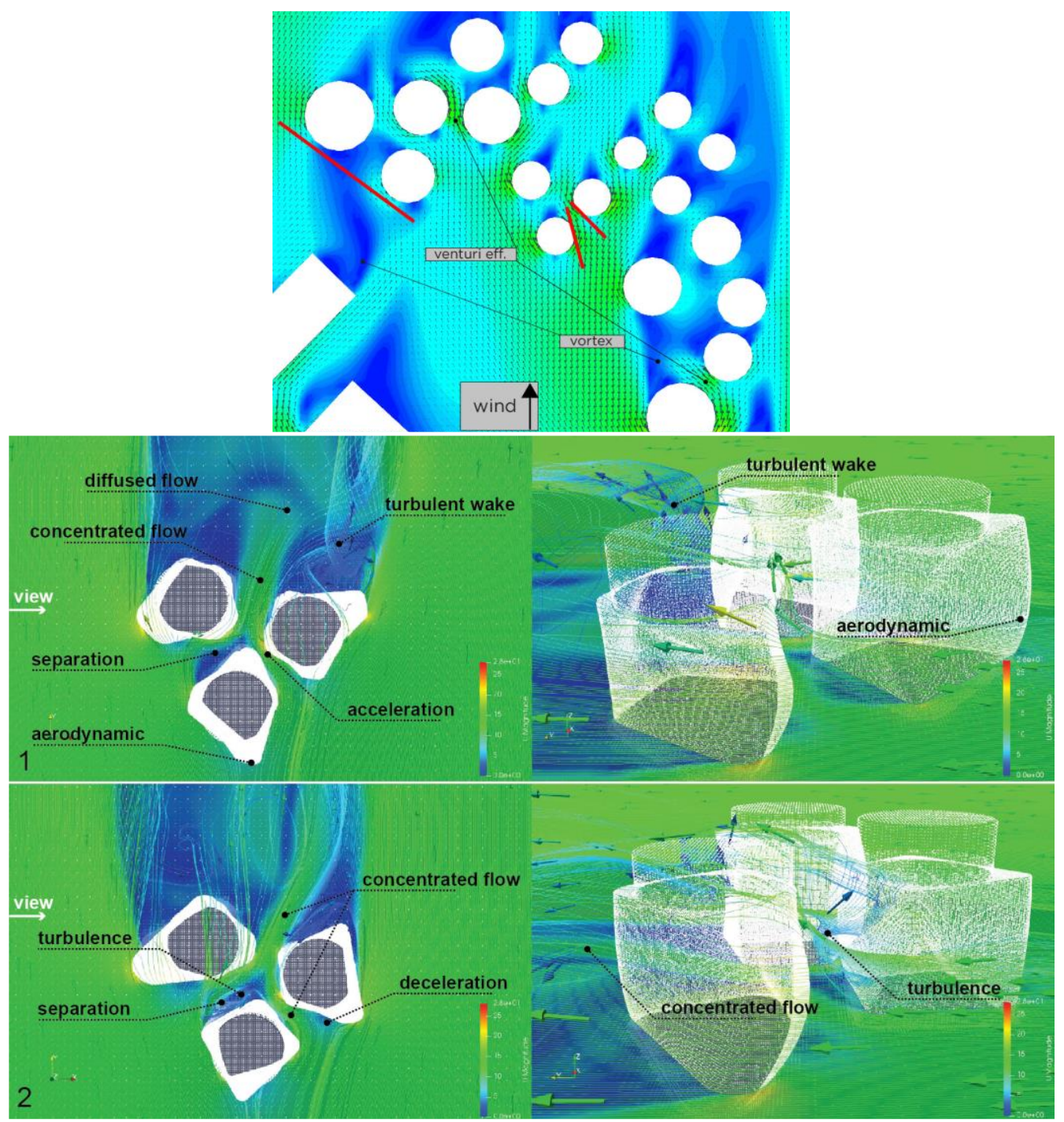

Figure 1: Southern wind in Loudden docks (focus area is in circle) - two shape modifications, FlowBrane (author: L. Kabosova)

\subsection{Aerodynamic properties}

Aerodynamic properties also fill the first point, which is briefly described.

The influence of air flow as well as the effect of air exchange in the interiors of buildings was the responsibility of Ing. Bullová, who published in 2019 on this research point: 
1) Impact of air permeability in selected reference room / Bullová - 2019, In: Design of energy efficient buildings 2019: Proceedings of Scientific Papers. - TUKE Košice $(\mathrm{SK})$ :

\subsection{Lighting properties}

The impact of light on the working environment was addressed by Ing. Erika Dolnikova, PhD., [3], [4], [5]. In 2019, several publications were published:

1) Evaluation of Daylighting in Selected Office Rooom: Case Study / Dolníková - 2019, In: SSP - Journal of Civil Engineering, TUKE, Kosice (SK)

2) Visual Assessment in Industrial Environment: A Case Study / Dolníková, Katunský 2019, In: Environments (CH)

3) Assessment of Daylight in a Selected Office through Simulation Programs: A case study / Dolníková - 2019, In: e-GFOS: Electronic Journal of the Faculty of Civil Engineering Osijek (HR)

4) Visual Comfort Assistant in the Office: A Case Study / Dolnikova, Katunsky - 2019, In: SGEM 2019 conference proceedings, Nano, Bio and Green - Technologies for a Sustainable Future: Green Buildings Technologies and Materials, Green Design and Sustainable Architecture, Space Technologies and Planetary Science. - Sofia (BG)

5) Assessment of Working Environment in Terms of Visual Perception / Katunský, Dolníková - 2020, In: Proceedings of CEE 2019, Cham, Springer, $(\mathrm{CH})$

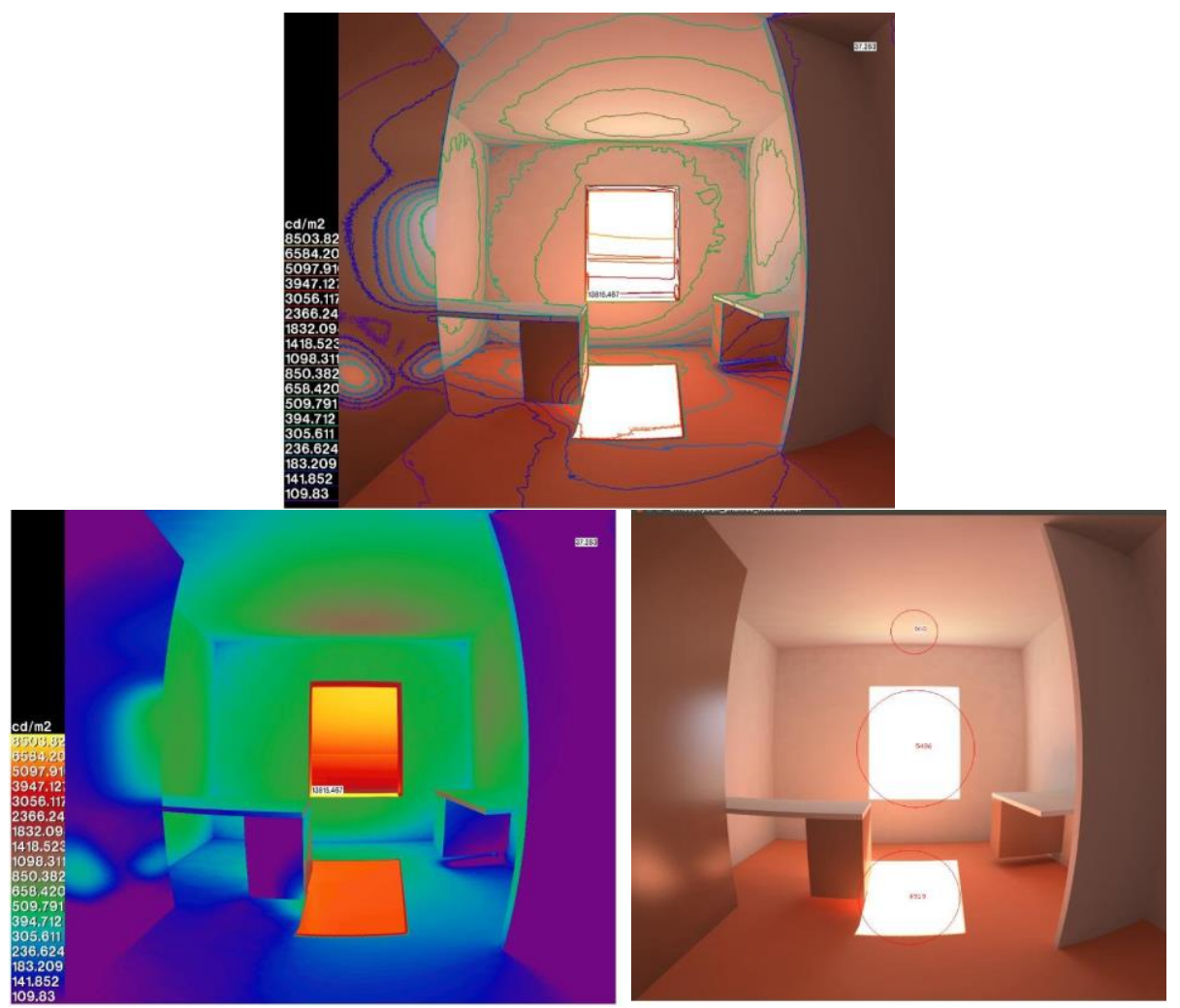

Figure 2: Evaluation of luminous intensity, potential glare (dazzling eyes) by Radiance program (author: E. Dolníková) 


\subsection{Energy assessment of buildings}

Published contributions resulted from the solution of the previous grant, which was followed by this project [6]. In 2019 the following publications were concerned:

1) The Impact of Various Factors on the Energy Efficiency of Selected Types of Family Houses / Katunský, Farárik - 2019, In: Proceedings of the 12th International EnviBUILD Conference, Bratislava (SK)

2) Comparison of Energy Efficiency Properties of Individual Houses / Katunský, Farárik - 2019, In: Proceedings of SGEM 2019. 2.6 Nano, Bio and Green - Technologies for Sustainable Future: Technologies and Materials for Green Buildings, Eco-Design and Sustainable Architecture, space technology and planetary science. - Sofia (BG)

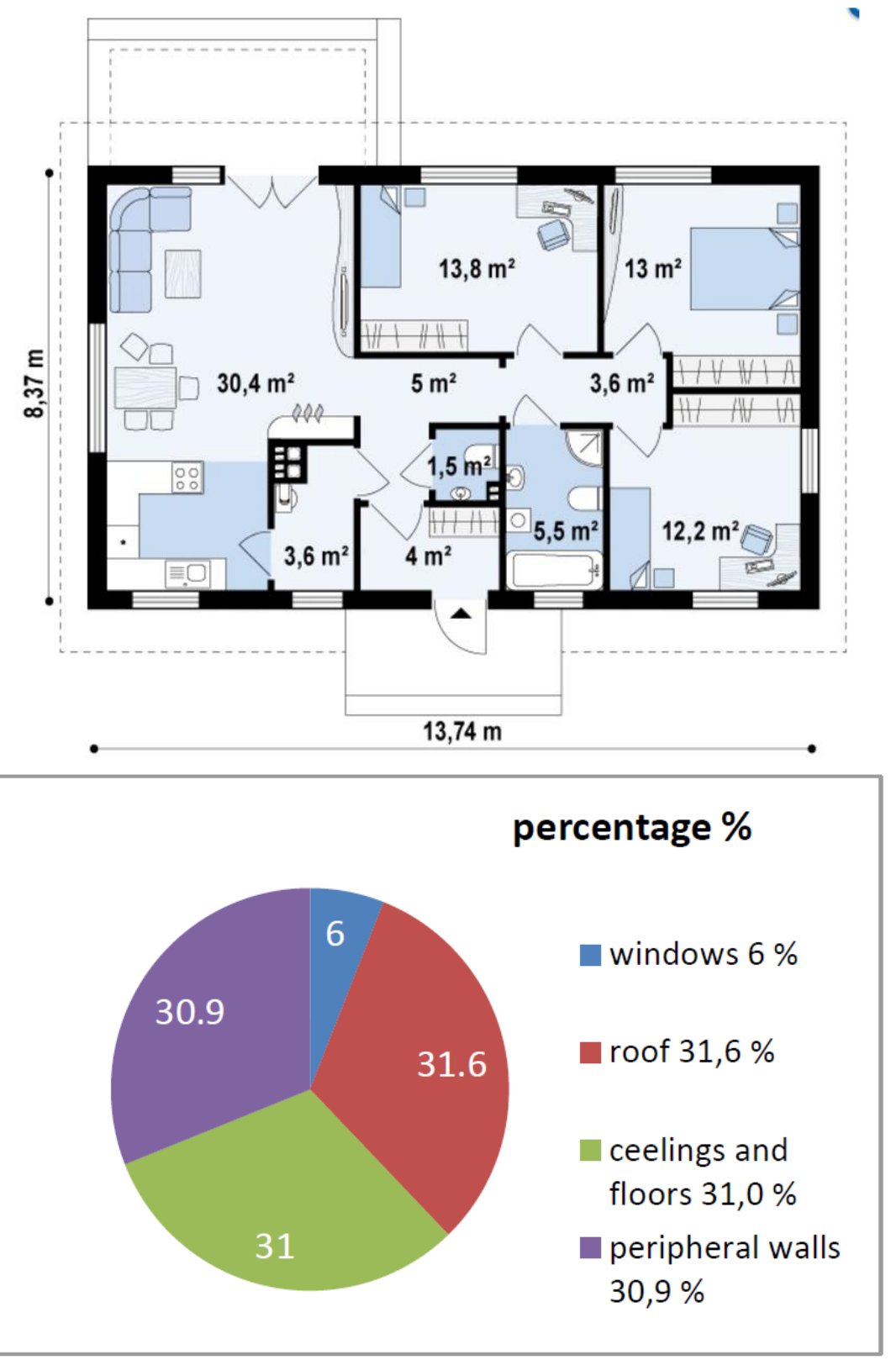



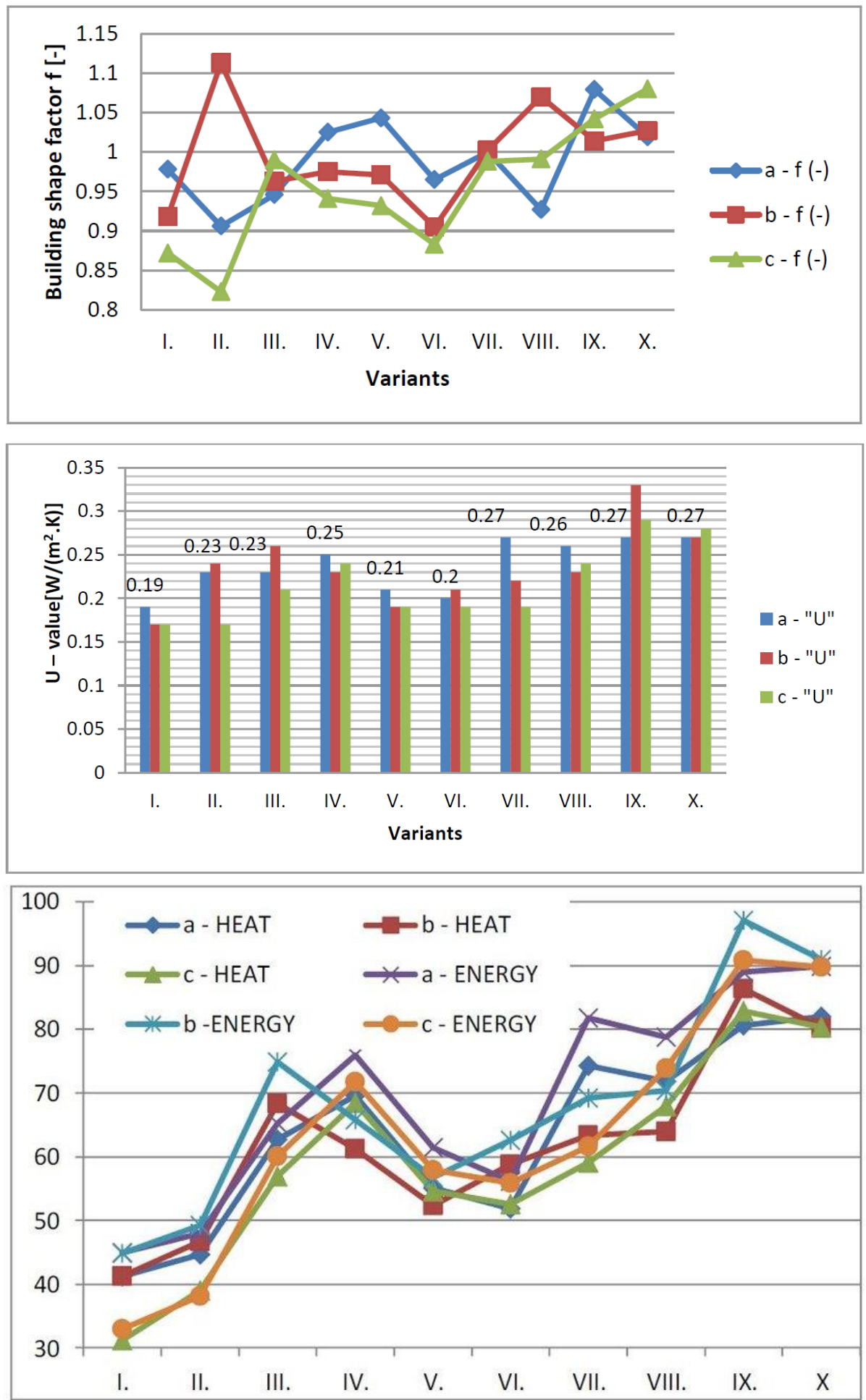

Figure 3: Assessment of heating demand (HEAT) and heating energy (ENERGY) $\mathrm{kWh} /\left(\mathrm{m}^{2} \mathrm{a}\right.$.), Part of heat losses in individual parts of single-store houses according to Katunský/Farárik 


\subsection{Heat-moisture properties}

The evaluation of thermal-moisture properties was carried out by several researchers [7], [8], [9], but mainly by Ing. Marek Zozulak, PhD, [10]. In 2019 these were the publications:

1) Simulation of window connection joint using ham model and temperature field model / Zozulák, Katunský - 2019, In: Thermal Protection of Buildings 2019: Designing of Building Structures and Buildings: Proceedings of 20th International Conference. Bratislava (SK)

2) The influence of the initial condition in the transient thermal field simulation inside / wall / Zozulák, Vertal', Katunský - 2019, In: Buildings, $(\mathrm{CH})$

3) Selected Problems of Thermal Insulation of Historical Buildings / Katunská, Katunský, Labovská - 2019, in Selected Scientific Papers / Journal of Civil Engineering (SK)
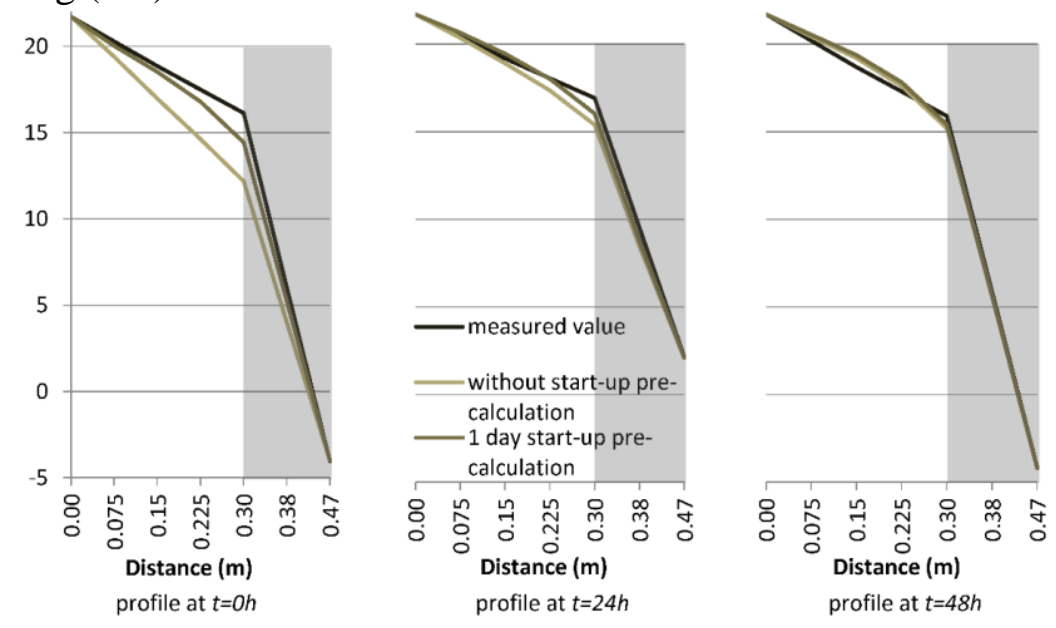

A/
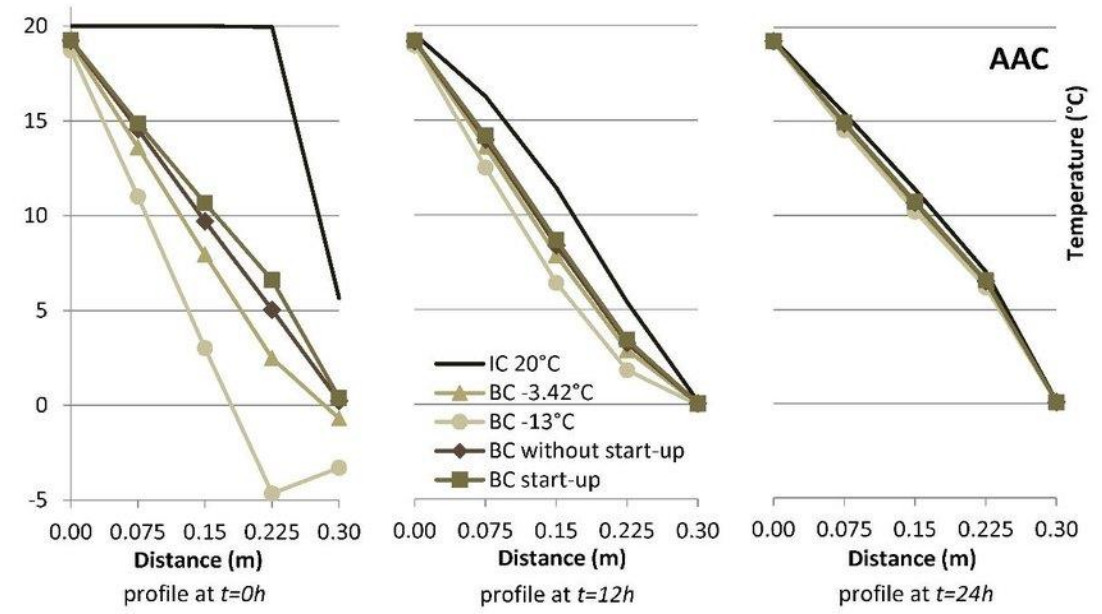

$\mathrm{B} /$

Figure 5: A / Temperature profile across the cell wall at $\mathrm{t}=0,24$ and $48 \mathrm{~h}$, with and without preliminary calculations

$\mathrm{B} /$ Temperature profile through a single AAC test wall at $\mathrm{t}=0 \mathrm{~h}, \mathrm{t}=12 \mathrm{~h}$ and $=24 \mathrm{~h}$ for five cases under initial conditions (author M. Zozulák) 


\subsection{Properties of materials, sandstone, transparent wood}

Material properties, especially transparent wood and sandstone, were studied by $\mathrm{PhD}$ students Ing. arch. Viktor Karl'a [11], and Ing. Pavol Jaroš. In 2019 these were the following publications:

1) Structural elements of transparent wood in architecture / Karl'a - 2019, In: PhD student seminar 2019: in the field: Building construction - Košice (SK)

2) Update on Research on Transparent Wood / Karla - 2019, In: YS2019 - Young Scientist 2019: Proceedings of the 11th International Scientific Conference on Civil and Environmental Engineering for PhD. Students and Young Scientists - Bristol (GB)

3) Sandstone as Building Material in Eastern Slovakia / Jaroš, Vertal' - 2019, In: PhD Seminar 2019: in the field: PS - TUKE Košice (SK)

4) Water transport in historical buildings / Jaroš, Vertal 2019, In: YS2019 - Young Scientist 2019: proceedings of the 11th International Scientific Conference on Civil and Environmental Engineering for $\mathrm{PhD}$. Students and Young Scientists, IOP Publishing - Bristol (GB)

\subsection{LCA method}

Life Cycle Assessment was solved in 2019 besides previous topics. Associated professor Vilčeková from the Institute of Environmental Engineering was as the tutor for doctoral student Ing. arch Tomková. They published together some articles:

1) Analysis of the life cycle of family houses in terms of sustainability in construction / Moňoková, Vilčeková, Tomková - 2019, In: Sustainability and digitization in construction - TUKE Košice (SK)

2) Primary and recycled materials from the perspective of LCA analysis / Tomková, Moňoková, Vilčeková - 2019, In: Cassotherm 2019: Non-Conference Proceedings of Scientific Papers. - TUKE Košice (SK)

3) Analysis of the current situation in the field of LCA / Tomková, Vilčeková - 2019, In: YS2019 - Young Scientist 2019: Proceedings of the 11th International Scientific Conference on Civil and Environmental Engineering for PhD. Students and Young Scientists - IOP Publishing Bristol (GB)

4) Analysis of the current situation in LCA (Life Cycle Assesment) / Tomková - 2019, In: PhD Seminar 2019: in field: PS - TUKE Košice (SK)

5) Primary and Recycled Materials from LCA Analysis / Tomková, Moňoková, and Vilčeková - 2019, In: Indoor Climate of Buildings 2019: Energy Management for a better Indoor Environment - Slovak Society for Environmental Engineering Bratislava (SK)

\section{Conclusion}

The paper presents the results of the previous research project VEGA 1/0674/18 "Theoretical and Experimental Analysis of Architectural and Structural Shapes and Fragments of Building Structures for Demanding Climate Conditions", which is planned for 2018-2021. Especially to the change of the research team, this also influenced the overall work on individual tasks. 
With regard to the staffing of the researchers and the acceptance of new $\mathrm{PhD}$ students, some of the objectives and / or methodology were modified so that the status of the solution could be realistic. As it was presented, most of the activities were carried out in areas where the researchers are specialized or professionally oriented [12]. The main task is to solve constructional details of buildings from the point of view of physical aspects under difficult conditions. This can be seen in the outputs of the second year of the solution. It was the effect of difficult conditions, whether it affected the effect of wind, temperature differences, but also the effect of sun rays, glare, etc.

\section{Acknowledgements}

The paper presents partial research results of project VEGA 1/0674/18

\section{References}

[1] Kabošová, L., Foged, I., Kmet', S., \& Katunský, D. (2019). Hybrid design method for windadaptive architecture. International Journal of Architectural Computing, 17(4), 307-322.

[2] Kabošová, L., Kmet', S., \& Katunský, D. (2019). Digitally designed airport terminal using wind performance analysis. Buildings, 9(3), 59.

[3] Dolnikova, E., \& Katunsky, D. (2019). Visual Comfort Assessment in an Industrial Environment: A Case Study. Environments, 6(5), 54

[4] Dolnikova, E. (2019). Assessment of Daylight in the Selected Office through Simulation Programs: a case study. e-Gfos, 10(18), 82-92.

[5] Katunsky, D., \& Dolnikova, E. (2019), Assessment of the Working Environment in Terms of Visual Perception. In International Conference Current Issues of Civil and Environmental Engineering Lviv-Košice-Rzeszów (pp. 145-152). Springer, Cham

[6] Katunský, D. \& Farárik, M. (2019), The Impact of Various Factors on the Energy Performance of Selected Types of Family Houses. In: Applied Mechanics and Materials (Vol. 887, pp. 109116). Trans Tech Publications

[7] Tudiwer, D., Vertal', M., Korjenic, A., \& Čakyová, K. (2019), Abbildung der Wärmedämmenden Wirkung eines Fassadengebundenen Begrünungssystems in einem Simulationsmodell, Bauphysik, 41(3), 155-161.

[8] Richard Baláž, R. \& Tóth, S. (2019) Green roofs and its measurement in: Advances and Trends in Engieneering Sciences and Technologies III., Londýn (Vel'ká Británia): CRC Press, s. 293298

[9] Katunská, J., Katunský, D., \& Labovská, V. (2019), Selected problems of thermal insulation of historical buildings. Selected Scientific Papers-Journal of Civil Engineering, 14 (1), 67-74.

[10] Zozulák, M., Vertal', M., \& Katunský, D. (2019), The Influence of the Initial Condition in the Transient Thermal Field Simulation Inside a Wall, Buildings, 9 (8), 178.

[11] Karl'a, V. (2019, June). Update on Research on Transparent Wood. In IOP Conference Series: Materials Science and Engineering (Vol. 566, No. 1, p. 012015). IOP Publishing.

[12] Katunský, D. (2020), Výskum budov v náročných klimatických podmienkach a výskum priamej zložky D.O. v architektonickom a interiérovom prostredí budov (súčasný stav riešenia). In: 12. ročník Seminár doktorandov ÚPS Zborník príspevkov ISBN 978-80-553-3519-3 (Vol. 12, pp. 53-60). TUKE Košice 